\title{
Evaluation of whey fermented by Enterococcus faecium in consortium with Veilonella parvula in ruminant feeding
}

\author{
Juliana Silva de Oliveira ${ }^{1}$, Augusto César de Queiroz ${ }^{1}$, Hilário Cuquetto Mantovani ${ }^{1}$, Geraldo \\ Fábio Viana Bayão ${ }^{1}$, Edenio Detmann ${ }^{1}$, Edson Mauro Santos ${ }^{2}$, Thiago Carvalho da Silva ${ }^{1}$ \\ 1 UFV - Universidade Federal de Viçosa. \\ 2 UFPB - Universidade Federal da Paraíba.
}

\begin{abstract}
The objective of this study was to evaluate the whey fermented by Enterococcus faecium in consortium with Veilonella parvula on the in vitro growth of ruminal bacteria and as a supplement in the cattle diet. In the in vitro experiment, a randomized design, with the following combinations was used: ruminal bacteria; ruminal bacteria and inactive whey; ruminal bacteria and active whey; and active whey. In the in vivo experiment, five fistulated Zebu Holstein-Zebu crossbred heifers were distributed in a $5 \times 5$ Latin square. Supplements were formulated without the addition of whey, with the addition of two levels of unfermented whey ( 2.5 and 5 L/day) or two levels of fermented whey ( 2.5 and 5 L/day). A positive effect of the whey fermentation was detected on the consumption of dry matter, organic matter, crude protein, ether extract, nonfiber carbohydrates and neutral detergent fiber, corrected for ash and protein in kg/day. No effects of whey were observed on the $\mathrm{pH}$ and concentration of rumen ammonia nitrogen, serum concentration of urea and glucose, urinary excretion of urea or nutrient digestibility, except for the total digestible nutrients. Supplementation with whey improved the apparent nitrogen balance, but supplementation with fermented whey decreased the intestinal flow of microbial nitrogen and microbial synthesis efficiency in relation to the unfermented whey. The whey fermentation process does not optimize the physiological responses of heifers supplemented with 2.5 and $5.0 \mathrm{~L}$ of whey.
\end{abstract}

Key Words: lactate, organic acids, propionic acid, rumen

\section{Introduction}

The feed cost, in the milk-producing or beef cattle farms, corresponds to an important proportion of the total production costs. Thus, methods which improve the efficiency of feed nutrients utilization by ruminants are of great value in the commercial production of these animals. Manipulation of ruminal fermentation has been one of the methods used to increase animal productivity.

Among the ruminal additives, organic acids have stood out. These food additives act in different ways on ruminal fermentation, improving animal performance, leaving no residue in products of animal origin (Krehbiel et al., 2003). As the international market demands food products free of any toxic substance (Stradiotti Júnior et al., 2001), organic acids are possible alternatives for improving the productivity of ruminants.

Despite few studies on them, the organic acids have provided effects on animal performance by increasing the production and percentage of milk components and improving feed efficiency and weight gain on animals (Khampa \& Wanapat, 2007, Kung et al., 1982).
Two rumen bacteria, Enterococcus faecium and Veilonella parvula, were isolated and, when inoculated in whey, increased levels of organic acids (acetate, propionate and succinate) (Ribeiro et al., 2009). Thus, the whey that, when in natura condition, has limited use in animal feed, due to excessive proportions of water and minerals, when fermented by these organisms could improve animal performance by acting as a ruminal handler, being a source of organic acid and living bacteria users of lactose, lactate, and propionate producers. In addition, it can contain high amounts of propionic acid, being readily available source of energy for the ruminant animal.

The objective of this study was to evaluate the effect of whey fermented by an Enterococcus faecium and Veilonella parvula consortium on in vitro rumen microorganisms growth and on the diet of fistulated heifers, considering the dry matter and nutrient intake, ruminal $\mathrm{pH}$, and serum urea and glucose concentrations, urinary excretion of urea, production of bacterial proteins, nitrogen compounds balance, and apparent total digestibility. 


\section{Material and Methods}

The in vitro experiment was conducted at Laboratório de Microbiologia de Anaeróbicos in the Departamento de Microbiologia of Universidade Federal de Viçosa - UFV, in Viçosa, Minas Gerais.

One steer fistulated in the rumen was maintained on a Brachiaria decumbens pasture grass, as a donor of rumen fluid. The steer was housed in Laboratório de Animais in the Departamento de Zootecnia of UFV.

Fermented whey was used in the experiments. The whey was initially dehydrated and re-suspended in water containing $40 \mathrm{~g} / \mathrm{L}$ lactose.

Then, the $\mathrm{pH}$ was adjusted to 7.0 with $\mathrm{NaOH}$ to $1.0 \mathrm{M}$. The whey was, then, autoclaved, saturated with carbon dioxide and inoculated with Enterococcus faecium and Veilonella parvula (3\% of the medium). The whey was kept for 48 hours at $39^{\circ} \mathrm{C}$ with bubbling of constant carbon dioxide, and constantly adjusted to $\mathrm{pH} 7.0$ by adding $\mathrm{NaOH}$. After, it was frozen for later use in incubations.

One liter of rumen fluid was collected from fistulated cattle in the rumen, and immediately transported to the laboratory in a thermos. It was then placed at rest for 30 minutes at $39^{\circ} \mathrm{C}$, and, after the formation of the liquid interfaces, the intermediary fluid was removed, which was centrifuged at $5000 \mathrm{x}$ g for 10 minutes, discarding the supernatant to obtain the inoculum containing the active microbial population (pellet).

The formed pellet, which contained the predominant microorganisms in the rumen fluid, was re-suspended in synthetic medium $(40 \mathrm{~mL}$ of saline solution $\mathrm{A}$ - which contains, per liter: $7.3 \mathrm{~g} \mathrm{~K}_{2} \mathrm{HPO}_{4} * 3 \mathrm{H}_{2} \mathrm{O} ; 40 \mathrm{~mL}$ of saline solution B - which contains, per liter: $6.0 \mathrm{~g}$ of $\mathrm{K}_{2} \mathrm{HPO}_{4}$, $12.0 \mathrm{~g}$ of $\left(\mathrm{NH}_{4}\right)_{2} \mathrm{SO}_{4}, 12,0 \mathrm{~g}$ of $\mathrm{NaCl}, 2.5 \mathrm{~g}$ of $\mathrm{MgSO}_{4} * 7 \mathrm{H}_{2} \mathrm{O}$ and $1.6 \mathrm{~g}$ of $\mathrm{CaCl}^{*} 2 \mathrm{H}_{2} \mathrm{O} ; 0.50 \mathrm{~g}$ of yeast extract; $1.0 \mathrm{~g}$ of trypticase - Trypticase, BBL Microbiology Systems, Cockesyille, MD; $0.60 \mathrm{~g}$ of cysteine hydrochloride; $1.0 \mathrm{ml}$ of resazurin; $4.0 \mathrm{~g}$ of sodium carbonate; and $870 \mathrm{~mL}$ of water) autoclaved and saturated with carbon dioxide. Another centrifugation was performed at $5000 \mathrm{x}$ g for 10 minutes, with the supernatant discarded again. The pellet formed in the last centrifugation was, then, re-suspended in synthetic medium autoclaved and saturated with carbon dioxide (Rumen Bacteria) (Oliveira et al., 2011).

The design was completely randomized, with four replications and four combinations. The combinations were: rumen bacteria, rumen bacteria + inactive whey, rumen bacteria + active whey and active whey. In the combination of rumen bacteria + inactive whey, the fermented whey was used as previously described (inactive whey).
In rumen bacteria + active whey and active whey combinations, fermented whey was used by the same procedure of combining rumen bacteria + inactive whey. However, after incubation, the whey was not frozen, but immediately used in the respective combinations. Thus, the whey contained living cells of Enterococcus faecium and Veilonella parvula (active whey).

The incubation tubes of the rumen bacteria combination contained $9.0 \mathrm{~mL}$ of inoculum of rumen bacteria; $120 \mathrm{mg}$ glucose, and pure synthetic culture medium autoclaved and saturated with carbon dioxide in necessary quantities to achieve $30 \mathrm{~mL}$ of medium in total. The incubation tubes and combinations rumen bacteria + inactive whey and rumen bacteria + active whey contained $9.0 \mathrm{~mL}$ of rumen bacteria, $7.5 \mathrm{~mL}$ of inactive or active whey, $120 \mathrm{mg}$ glucose, and pure synthetic culture medium autoclaved and saturated with carbon dioxide in quantities needed to reach $30 \mathrm{~mL}$ of medium in total. The incubation tubes of active whey combination contained $7.5 \mathrm{~mL}$ of active whey, $120 \mathrm{mg}$ glucose, and pure synthetic culture medium autoclaved and saturated with carbon dioxide in quantities necessary to achieve $30 \mathrm{~mL}$ of medium in total.

Incubations were carried out in calibrated glass syringes with a capacity of $100 \mathrm{~mL}$ (HÄBERLE Labortechnik -FORTUNA ${ }^{\circledR}$ Germany) and maintained at a temperature of $39^{\circ} \mathrm{C}$, in agitation (70 rpm), for 48 hours (Magalhães et al., 2010). At 0, 1, 2, 4, 6, 8 12, 24, $32 \mathrm{~m}$ and 48 hours, readings of the volume of gas produced in the incubation were taken (Magalhães et al., 2010).

Moreover, at 0 and 24 hours, a 1.0-mL sample of each treatment was collected, placed in eppendorf tube and centrifuged at $5200 \mathrm{x}$ g, for 10 minutes, and the supernatant discarded and the pellet and the pellet re-suspended in saline $(0.9 \% \mathrm{NaCl})$, centrifuged again and separated from supernatants, and then re-suspended in saline $(0.9 \% \mathrm{NaCl})$ and frozen for subsequent quantification of microbial protein by the Bradford method (1976).

The data were subjected to analysis of variance, comparing the means by Tukey test $(\alpha=0.05)$.

The in vivo experiment was conducted from October to December 2007, at the Departmento de Zootecnia, UFV, Viçosa, Minas Gerais.

Five Zebu Holstein-Zebu crossbred heifers fistulated in the rumen, with average body weight of $350 \mathrm{~kg}$ were distributed in a $5 \times 5$ Latin square. Each animal was housed in an individual cage, provided with feeder and drinker.

An isoprotein diet was used, based on Tifton-85 Bermudagrass (Cynodon spp.) hay, roughage:concentrate ratio of 70:30 on dry matter basis, and formulated to meet the requirements, according to NRC (1996), of heifers 
weighing an average of $350 \mathrm{~kg}$, and body weight gain of approximately $0.70 \mathrm{~kg} /$ day.

The design used was a Latin square, arranged in a factorial scheme of $2 \times 2+1$ (two levels of unfermented whey, two levels of fermented whey and without the addition of whey). The supplements consisted of no addition of whey (control), addition of two levels of unfermented whey (2.5 and 5 L/day) and two levels of fermented whey by an Enterococcus faecium and Veilonella parvula consortium (2.5 and $5 \mathrm{~L} /$ day). The definition of whey levels was made from the in vitro experiment described above.

Whey fermented by the same procedure as the in vitro experiment described above was used. However, the whey was kept in incubation for 72 hours, and, after incubation, it was immediately used for feeding the heifers. The fermented whey had as main fermentation end products propionate, lactate, acetate and succinate, with an average concentration of (mM) 226.97; 158.30; 153.37; and 14.75, respectively.

The experiment consisted of five twelve-day periods, with five days of adaptation to the diet and seven days for data collection. Animals were kept confined and were fed twice daily ( 8 a.m. and 4 p.m.) in equal proportion, with feed supplied individually. Feed was supplied ad libitum, so that there were at least $10 \%$ of leftovers. The whey was homogenized with the feed, and provided in the animal feed, in two daily meals, in the same proportion. In order for the level of food supply to be properly adjusted, the leftovers were weighed daily.

However, the leftovers computed between the seventh and tenth day of each experimental period and the feed provided between the sixth and ninth days were used for quantification and evaluation of voluntary consumption. From them, composite samples were made for each experimental period for measurements of dry matter (DM), organic matter (OM), crude protein (CP), ether extract (EE), non-fiber carbohydrates (NFC), neutral detergent fiber (NDF), acid detergent fiber (ADF) and lignin, in which the analysis followed the specifications described in Silva \& Queiroz (2002) with the exception of NDF and ADF. The NDF content was estimated according to recommendations of Mertens (2002), with corrections for ash and protein contained in the NDF and ADF as recommended by Mertens (2002) and Licitra et al. (1996) (Table 1).

Fecal collection was performed on day 7 (6 a.m. and 2 p.m.), day 8 ( 8 a.m. and 4 p.m.), day 9 (10 a.m. and 6 p.m.), and day 10 (12 a.m. and 8 p.m.). The amount of fecal dry matter excreted was estimated by the concentration of indigestible neutral detergent fiber (iNDF), obtained after the in situ incubation of food, leftovers, and feces for a period of 240 hours (Casali et al., 2008). In the feces samples, DM, OM, CP, EE and NDFap were determined through the same methods that were used in the analysis of foods and leftovers.

On the sixth day of the experimental period, collects of rumen fluid samples were performed at 4 a.m., 8 a.m., 12 a.m., 4 p.m., 8 p.m., and 12 p.m. The $\mathrm{pH}$ and concentration of ruminal ammonia nitrogen of all periods of time were estimated. Immediate reading of $\mathrm{pH}$ in rumen fluid was performed with the digital potentiometer Dellta. Samples of rumen fluid were placed in 1.5-mL Eppendorf tubes and centrifuged at $5200 \mathrm{x} \mathrm{g}$ for 10 minutes, removing the supernatant, and transferring it to another eppendorf tube for analysis of ruminal ammonia nitrogen. All samples were frozen for further analysis. The ammonia concentration was determined by the colorimetric method of Chaney \& Marbach (1962). The test results for each period of time were used to calculate the average ruminal $\mathrm{pH}$ and the ruminal ammonia nitrogen of the treatments.

On the eleventh day, rumen contents were collected immediately before the morning feeding (Cecava et al., 1990) in order to obtain samples for microbial biomass for the

Table 1 - Composition of the concentrate, hay, non-fermented and fermented whey used in experimental diets

\begin{tabular}{lcccc}
\hline Item & Concentrate & Tifton hay 85 & Non-fermented whey & Fermented whey \\
\hline $\mathrm{DM}^{1}$ & 88.41 & 87.26 & 5.20 & 5.25 \\
$\mathrm{OM}^{2}$ & 98.54 & 94.05 & 92.31 & 92.30 \\
$\mathrm{CP}^{2}$ & 18.22 & 9.47 & 11.10 & 21.65 \\
$\mathrm{EE}^{2}$ & 0.99 & 1.68 & - & 21.87 \\
$\mathrm{NDF}^{2}$ & 20.81 & 70.83 & - & - \\
$\mathrm{NDFap}^{2}$ & 17.20 & 67.59 & 59.33 & - \\
$\mathrm{NFC}^{2,3}$ & 58.27 & 15.35 & - & - \\
ADFap $^{2}$ & 3.20 & 34.60 & - & - \\
Lignin $^{2}$ & 0.09 & 2.14 & - & - \\
\hline
\end{tabular}

DM - Dry matter; OM - organic matter; CP - crude protein; EE - ether extract; NDF - neutral detergent fiber; NDFap - neutral detergent fiber corrected for ash and protein; NFC - non-fiber carbohydrates; ADFap - acid detergent fiber corrected for ash and protein.

$1 \mathrm{dag} / \mathrm{kg}$ of natural matter.

$2 \mathrm{dag} / \mathrm{kg}$ of dry matter.

3 NFC $=$ OM - (CP + EE + NDFap $)$. 
determination of microbial efficiency. Subsequently, they were centrifuged and dried in an oven with forced ventilation $\left(60^{\circ} \mathrm{C}\right)$, processed in a ball-type mill and stored for further analysis of DM and purine bases (Ushida et al., 1985).

Spot urine samples were obtained from all heifers in the eighth, tenth, and twelfth days of each experimental period, at 12 a.m., by spontaneous micturition. The urine of each animal was filtered and a rate of $10 \mathrm{~mL}$ was removed, diluted in $40 \mathrm{~mL}$ of sulfuric acid at $0.036 \mathrm{~N}$ and frozen for posterior analysis of urea, total nitrogen, creatinine, allantoin, and uric acid (purine derivatives). The concentrations of creatinine and uric acid in urine were estimated by the modified Jaffé method (Bioclin K016-1), the concentration of urea in the urine by the colorimetric method (PAP-UOD, Bioclin K052), urinary levels of allantoin by the colorimetric method, in accordance to Chen and Gomes (1992), and the total nitrogen concentration was estimated by the Kjeldahl method (Silva \& Queiroz, 2002). The conversion of urea into urea nitrogen was done by multiplying the values by the factor 0.466 .

The total volume of urine was estimated by the relation between creatinine concentration in urine and its excretion per unit of body weight, using the following equation (Chizzotti, 2004):

$\mathrm{EC}=32.27-0.011093 \times \mathrm{BW}$

where: $\mathrm{EC}=$ daily excretion of creatinine $(\mathrm{mg} / \mathrm{kg} \mathrm{BW})$ and BW = body weight $(\mathrm{kg})$.

The excretion of purine derivatives was calculated through the sum of allantoin and uric acid excreted in the urine.

The absorbed purines were calculated from the excretion of purine derivatives by the equation (Verbic et al., 1990): $\mathrm{AP}=\mathrm{DP}-0.385 \times \mathrm{BW}^{0.75}$

\subsection{5}

where: $\mathrm{AP}=$ absorbed purines ( $\mathrm{mmol} /$ day), $\mathrm{PD}=$ excretion of purine derivatives (mmol/day); $0.85=$ absorbed purine recovery as purine derivatives in urine; and $0.385=$ endogenous excretion of purine derivatives in urine (mmol/kg BW ${ }^{0.75}$ ).

The synthesis of microbial nitrogen compounds in the rumen was estimated as a function of absorbed purines and the relation $\mathrm{N}_{\mathrm{RNA}}$ : $\mathrm{N}_{\text {TOTAL }}$ in the bacteria, according to Chen and Gomes (1992):

$$
\mathrm{N}_{\text {mic }}=\frac{70 \times \mathrm{PA}}{0.83 \times \mathrm{R} \times 1000}
$$

where: $\mathrm{N}_{\text {mic }}=$ microbial nitrogen compounds flow into the small intestine (g/day), $\mathrm{R}=\mathrm{N}_{\mathrm{RNA}}$ : $\mathrm{N}_{\text {TOTAL }}$ ratio in the bacteria; 70 = nitrogen content in purines $(\mathrm{mg} / \mathrm{mol})$; and $0.83=$ intestinal digestibility of microbial purines.
Blood collection via the jugular vein of all calves was performed at 12 a.m., on the twelfth day of each experimental period, using vacuntainer tubes. After the collection, samples were immediately centrifuged (2500 x g for 15 minutes) and the serum was frozen for further analysis of urea and glucose, using commercial kits.

The TDN (total digestible nutrients) of food was calculated according to the NRC (1996): $\mathrm{TDN}=\mathrm{DCP}+\mathrm{DNFC}+\mathrm{DNDFap}+2.25 \mathrm{DEE}$ where: $\mathrm{DCP}=$ digestible crude protein; $\mathrm{DNFC}=$ digestible non-fiber carbohydrates; NDFap = digestible neutral detergent fiber corrected for ash and protein and DEE = digestible ether extract.

Data were subjected to analysis of variance and the mean values were compared adopting $\alpha=0.10$ through orthogonal contrasts between the presence and absence of serum in the diet, levels of serum (2.5 and 5.0 liters) in the feed, and the absence and the different levels of whey in the ration. All statistical procedures were conducted using SAS statistical package (Statistical Analysis System, 2001).

\section{Results and Discussion}

The concentration of microbial protein at time zero was higher $(\mathrm{P}=0.0032)$ in the active or inactive whey media, compared with the medium that contained only rumen bacteria. After 48 hours of incubation, the microbial protein concentration remained higher $(\mathrm{P}=0.0025)$ in media with rumen bacteria and active or inactive whey, compared with the one which contained only rumen bacteria. The medium containing only whey did not differ from other assets.

The highest concentration of microbial protein at zero time in the combinations containing the whey fermented by Enterococcus faecium and Veilonella parvula may be due to the presence of these bacteria in whey. Thus, the bacteria Enterococcus faecium and Veilonella parvula contained in whey were also counted as microbial protein in those combinations containing the whey.

There was microbial growth during 48 hours of incubation in the medium containing only active whey (i.e., cultures containing Enterococcus faecium and Veilonella parvula), showing that these microorganisms continue the processes of fermentation and hence microbial growth after being added to another medium other than the whey.

The term direct-fed microbial is defined as a source of live microorganisms that occurs naturally (Krehbiel et al., 2003) and has beneficial effects on the animal that will be the host. The whey fermented by Enterococcus faecium and Veilonella parvula when added in the rumen shortly after being fermented may act as direct-fed microbial. The whey 
fermented by a Enterococcus faecium (which uses lactose turning it into lactic acid) and Veilonella parvula (fermenting lactic acid to propionic acid and acetate) consortium, when added to diet and ingested by ruminants, can continue the lactose fermentation process, and also for other carbohydrates and lactate, increasing the propionic acid production in the rumen (Melo, 2007).

When the values of microbial growth between zero time and 48 hours of incubation ( $\Delta, \mathrm{mg} / \mathrm{L}$ ) were checked, the medium containing rumen bacteria and inactive whey presented higher microbial growth than the ones with only rumen bacteria or only active whey. The whey fermented by Enterococcus faecium and Veilonella parvula consortium, containing these inactive microorganisms, may have stimulated the growth of rumen bacteria. The stimulating effect of fermented whey on rumen bacteria may be related to the concentration of propionic and lactic acids in the whey. Oliveira et al. (2011) found that propionic and lactic acids stimulate the growth of ruminal microorganism populations.

Microbial growth between zero time and 48 hours of incubation, in the medium with rumen bacteria and active whey, did not differ from that which contained only rumen bacteria (Table 2). The bacterial species Enterococcus faecium and Veilonella parvula are likely to compete with rumen bacteria for the substrates contained in the culture medium. This competition may have inhibited the growth of the whole microbial mass contained in the culture medium.

There was a higher gas production accumulated in the 48 hours of incubation and production of gas per hour in the medium with rumen bacteria and active whey and in the one with only active whey (Table 2). The bacterial species Enterococcus faecium and Veilonella parvula seem to ferment substrates in the medium faster than the rumen bacteria, considering that the only medium that contained Enterococcus faecium and Veilonella parvula presented higher gas production over time and also per hour than the one which contained only rumen bacteria or rumen bacteria contained in addition to the whey with inactive
Enterococcus faecium and Veilonella parvula. This characteristic of these organisms can be beneficial when considering that it makes them fully viable in the rumen environment, or negative when considering that these microorganisms, by subtracting the source of other nutrients from rumen microorganisms, may inhibit them.

The lack of significance in the production of gas from the medium containing only active whey and the one containing rumen bacteria and active whey confirms the competition that occurs between the bacteria contained in whey and rumen bacteria for the substrate. As a result of competition, the active whey probably did not stimulate the growth of rumen bacteria.

This competition for the substrate did not happen in the combination that contained rumen bacteria and inactive whey. Because the bacterial species Enterococcus faecium and Veilonella parvula no longer have the ability of fermenting the substrate and of growing, in media containing rumen bacteria and inactive Enterococcus faecium and Veilonella parvula, no competition for substrate occurred, highlighting the stimulant effect of organic acids on rumen microorganisms.

There was effect $(\mathrm{P}<0.10)$ of supplementation with whey and fermented and unfermented whey levels on EE intake, in $\mathrm{kg} /$ day of heifers in the in vivo experiment (Table 3). When the animals were supplemented with whey, there was a greater consumption of lipids in relation to non-supplemented animals. EE intake was higher, too, when added in higher whey doses to the diet.

The fermented and unfermented whey also showed similar high levels of ether extract $(21.65 \%$ and $21.87 \%$ in $\mathrm{DM})$. The addition of whey in the diet of heifers increased the ether extract content of diet; therefore, the animals consuming whey ingested higher content of EE in $\mathrm{kg} /$ day compared with the control group, probably due only to the largest EE content in the diet. Similarly, the addition of whey at higher levels in the diet of heifers provides a higher content of ether extract in the basal diet than the lower levels.

Table 2 - Microbial protein at zero hour (Ptn $0 \mathrm{~h}$ ) and after 48 hours of incubation ( $48 \mathrm{~h}$ Ptn), microbial growth between zero time and 48 hours of incubation $(\Delta)$, cumulative gas production within 48 hours of incubation (Gas) and production of gas per hour for different combinations

\begin{tabular}{|c|c|c|c|c|c|c|}
\hline Item & $\mathrm{RB}$ & RBIW & RBAW & $\mathrm{AW}$ & CV (\%) & $\mathrm{P}$ \\
\hline Ptn 0 h, mg/L & 298.9b & $765.6 \mathrm{a}$ & $821.1 \mathrm{a}$ & $707.2 \mathrm{a}$ & 25.7 & 0.0032 \\
\hline Ptn 48 h, mg/L & $787.8 \mathrm{~b}$ & $1798.9 \mathrm{a}$ & $1634.1 \mathrm{a}$ & $1332.2 \mathrm{ab}$ & 21.8 & 0.0025 \\
\hline$\Delta, \mathrm{mg} / \mathrm{L}$ & 488.9b & $1033.3 \mathrm{a}$ & $813.0 \mathrm{ab}$ & $625.0 \mathrm{~b}$ & 30.6 & 0.0112 \\
\hline Gas, mL & $118.50 \mathrm{~b}$ & $126.50 \mathrm{~b}$ & $166.75 a$ & $159.25 a$ & 7.9 & 0.0001 \\
\hline Gas, mL/hour & $2.47 b$ & $2.65 b$ & $3.47 \mathrm{a}$ & $3.35 \mathrm{a}$ & 7.8 & 0.0001 \\
\hline
\end{tabular}

RB - ruminal bacteria; RBIW - ruminal bacteria and inactive whey (Enterococcus faecium and Veilonella parvula); RBAW - ruminal bacteria and active whey (Enterococcus faecium and Veilonella parvula); AW - active whey (Enterococcus faecium and Veilonella parvula).

Means followed by lowercase letters in rows differ $(\mathrm{P}<0.05)$ by the Tukey test. CV - coefficient of variation. 
A significant effect $(\mathrm{P}<0.10)$ of whey fermentation was identified on DM, OM, CP, EE, and NFC NDF ap intake expressed in kg/day, when DM, OM, CP, EE, NFC and $\mathrm{NDF}_{\text {ap }}$ intake was higher in animals supplemented with fermented whey compared with the unfermented whey (Table 3).

The highest intake of DM and OM by heifers receiving fermented whey is possibly due to the better taste of the fermented whey in relation to the non-fermented one. During the test, it was observed that the animals had a preference for fermented whey when compared with the unfermented one. As the whey was supplied mixed in animal food, it boosted the intake of the total diet of heifers supplemented with fermented whey.

The higher intakes of CP, EE, NFC, and $\mathrm{NDF}_{\text {ap }}$ by animals receiving fermented whey can be a result of higher intakes of DM and OM. The basal diet supplied to heifers was the same for all supplements. Thus, as the differences in levels of these nutrients in the whey were not representative (except CNF), there were no differences in the nutritional value of the diet supplied to animals of the different supplements with whey. When the same diet is given to animals, the higher intake of nutrients is due to increased consumption of DM or OM, which correspond to the sum of nutrients in the diet.

There were no effects of fermented and unfermented whey on the digestibility of DM, OM, CP, EE, NFC or $\mathrm{NDF}_{\text {ap }}(\mathrm{P}>0.10)$. However, there was effect $(\mathrm{P}<0.10)$ of fermented and unfermented whey doses on dietary TDN (Table 4).

The TDN content was lesser when higher levels of whey were added in the diet. This was possibly due to the sum of small negative effects on the digestibility of all nutrients, which were not significant separately $(\mathrm{P}>0.10)$.

Fats, when in excess in the diet of ruminants, may influence negatively, through the covering of the fiber and toxic effects on microorganisms (Merchen et al., 1993). Diets containing higher amount of whey were those which had higher ether extract content in the dry matter and so, the whey in larger amounts may have negatively affected the TDN of the diet.

There were no effects $(\mathrm{P}>0.10)$ of the supplements on rumen $\mathrm{pH}$, rumen ammonia nitrogen, concentration of urea nitrogen in blood plasma, glucose in the blood plasma, concentration of urea nitrogen in urine or efficiency of microbial synthesis (Table 5).

Table 3 - Intake of nutrients and total digestible nutrients (TDN) as a function of supplementation with different doses of unfermented whey (W) and fermented whey (FW)

\begin{tabular}{|c|c|c|c|c|c|c|c|c|c|c|}
\hline \multirow[b]{2}{*}{ Intake } & \multicolumn{5}{|c|}{ Suplement } & \multirow[b]{2}{*}{ CV (\%) } & \multicolumn{4}{|c|}{ Contrast } \\
\hline & Cont & W2.5 & W5.0 & FW2.5 & FW5.0 & & Contr & Ferm & Level & Int \\
\hline & & & kg/day & & & & & & & \\
\hline DM & 7.684 & 7.140 & 8.194 & 8.724 & 8.664 & 13.1 & 0.3654 & 0.0503 & 0.3131 & 0.2609 \\
\hline $\mathrm{OM}$ & 7.338 & 6.810 & 7.812 & 8.322 & 8.262 & 13.1 & 0.3757 & 0.0502 & 0.3162 & 0.2615 \\
\hline CP & 0.969 & 0.903 & 1.025 & 1.111 & 1.115 & 12.4 & 0.2959 & 0.0227 & 0.2885 & 0.3234 \\
\hline EE & 0.114 & 0.135 & 0.175 & 0.158 & 0.184 & 10.2 & $<0.0001$ & 0.0464 & 0.0005 & 0.3293 \\
\hline NFC & 2.303 & 2.138 & 2.511 & 2.639 & 2.607 & 11.0 & 0.2289 & 0.0289 & 0.1809 & 0.1181 \\
\hline $\mathrm{NDF}_{\text {ар }}$ & 3.859 & 3.547 & 4.005 & 4.313 & 4.256 & 14.9 & 0.5760 & 0.0808 & 0.4657 & 0.3525 \\
\hline TDN & 4.311 & 4.127 & 4.644 & 4.997 & 4.836 & 15.8 & 0.3658 & 0.1272 & 0.5930 & 0.3163 \\
\hline
\end{tabular}

DM - dry matter; OM - organic matter; CP - crude protein; EE - ether extract; NFC - non-fiber carbohydrates; NDFap - neutral detergent fiber corrected for ashes and protein. Cont - No whey; W2.5 - 2.5 L of unfermented whey (W); W5.0 with - 5.0 L of W; FW2.5 - 2.5 L of fermented whey (FW); FW5.0 - 5.0 L of FW.

Contr - contrast of with or without whey; Ferm - contrast of W and FW; Level - contrast of whey levels; Interaction - contrast of W and FW at different levels. $\mathrm{CV}=$ coefficient of variation.

Table 4 - Digestibility of nutrients and levels of total digestible nutrients (TDN) of diets according to different doses of supplementation with unfermented (W) and fermented whey (FW)

\begin{tabular}{|c|c|c|c|c|c|c|c|c|c|c|}
\hline \multirow[b]{2}{*}{ Digestibility } & \multicolumn{5}{|c|}{ Suplement } & \multirow[b]{2}{*}{ CV (\%) } & \multicolumn{4}{|c|}{ Contrast } \\
\hline & Cont & W2.5 & W5.0 & FW2.5 & FW5.0 & & Contr & Ferm & Level & Int \\
\hline & & & $\mathrm{dag} / \mathrm{kg}$ & & & & & & & \\
\hline DM & 56.5 & 58.2 & 56.6 & 57.2 & 55.1 & 8.9 & 0.9230 & 0.6057 & 0.4322 & 0.9242 \\
\hline $\mathrm{OM}$ & 58.5 & 60.3 & 58.6 & 59.3 & 57.3 & 8.1 & 0.8822 & 0.6083 & 0.4142 & 0.9413 \\
\hline $\mathrm{CP}$ & 66.4 & 69.1 & 65.1 & 66.3 & 65.3 & 8.4 & 0.9705 & 0.6186 & 0.3399 & 0.5704 \\
\hline $\mathrm{EE}$ & 70.9 & 73.8 & 76.8 & 83.0 & 87.0 & 15.8 & 0.1598 & 0.1045 & 0.5343 & 0.9251 \\
\hline NFC & 81.0 & 82.5 & 80.6 & 81.4 & 78.1 & 4.4 & 0.8537 & 0.2824 & 0.1190 & 0.6633 \\
\hline NDF & 41.8 & 43.0 & 41.3 & 42.0 & 40.1 & 15.0 & 0.9600 & 0.6957 & 0.5273 & 0.9609 \\
\hline TDN & 66.1 & 65.0 & 57.8 & 62.5 & 56.6 & 12.0 & 0.1581 & 0.5789 & 0.0707 & 0.8477 \\
\hline
\end{tabular}

DM - dry matter; OM - organic matter; CP - crude protein; EE - ether extract; NFC - non-fiber carbohydrates; NDFap - neutral detergent fiber corrected for ashes and protein. Cont - No whey; W2.5 - 2.5 L of unfermented whey (W); W5.0 with - 5.0 L of W; FW2.5 - 2.5 L of fermented whey (FW); FW5.0 - 5.0 L of FW.

Contr - contrast of with or without whey; Ferm - contrast of W and FW; Level - contrast of whey levels; Interaction - contrast of W and FW at different levels.

$\mathrm{CV}=$ coefficient of variation. 
Table 5 - Rumen pH and concentrations of some ruminal, serum, and urine metabolites, and other selected indices, depending on the supplementation of calves with different levels of unfermented (S) and fermented whey (SF)

\begin{tabular}{|c|c|c|c|c|c|c|c|c|c|c|}
\hline \multirow[b]{2}{*}{ Item } & \multicolumn{5}{|c|}{ Suplement } & \multirow[b]{2}{*}{ CV (\%) } & \multicolumn{4}{|c|}{ Contrast } \\
\hline & Cont & W2.5 & W5.0 & FW2.5 & FW5.0 & & Contr & Ferm & Level & Int \\
\hline & & & Rumen & & & & & & & \\
\hline RAN & 11.85 & 12.80 & 13.21 & 13.90 & 13.90 & 27.8 & 0.3937 & 0.5928 & 0.9022 & 0.9012 \\
\hline $\begin{array}{l}\text { UNB } \\
\text { Glucose }\end{array}$ & $\begin{array}{l}17.01 \\
64.00\end{array}$ & $\begin{array}{l}14.63 \\
71.60\end{array}$ & $\begin{array}{l}\text { Blood } \\
15.38 \\
60.40\end{array}$ & $\begin{array}{l}15.98 \\
61.70\end{array}$ & $\begin{array}{l}16.03 \\
62.30\end{array}$ & $\begin{array}{l}17.9 \\
18.1\end{array}$ & $\begin{array}{l}0.3101 \\
1.0000\end{array}$ & $\begin{array}{l}0.4443 \\
0.4563\end{array}$ & $\begin{array}{l}0.7596 \\
0.3278\end{array}$ & $\begin{array}{l}0.7890 \\
0.2783\end{array}$ \\
\hline UNU & 209.70 & 200.38 & $\begin{array}{c}\text { Urine } \\
205.97\end{array}$ & 235.80 & 207.84 & 30.3 & 0.9321 & 0.5290 & 0.7041 & 0.5704 \\
\hline \multicolumn{11}{|c|}{ Other parameters } \\
\hline ANB & -53.50 & 16.65 & -7.56 & 8.53 & -13.78 & -110.0 & 0.0858 & 0.7878 & 0.3889 & 0.9715 \\
\hline Nmic & 146.38 & 142.92 & 172.09 & 76.85 & 96.50 & 35.3 & 0.3002 & 0.0041 & 0.2472 & 0.8166 \\
\hline MEF & 174.62 & 190.93 & 224.20 & 114.54 & 119.51 & 21.0 & 0.4894 & $<0.0001$ & 0.2396 & 0.3780 \\
\hline
\end{tabular}

$\mathrm{pH}$ - rumen pH; RAN (mg/dL) - rumen ammonia nitrogen; UNB (mg/dL) - urea nitrogen concentration in blood plasma; glucose (mg/dL) - glucose concentration in blood plasma; UNU (mg/dL) - urea nitrogen concentration in urine; ANB (g/day) - apparent nitrogen balance; Nmic (g/day) - intestinal flow of microbial nitrogen; MEF (g microbial $\mathrm{CP} / \mathrm{kg} \mathrm{TDN})$ - microbial efficiency.

Cont - without whey; W2.5 - with 2.5 L of unfermented whey (W); W5.0 - with 5.0 L of W; WF2.5 - with 2.5 L of fermented whey (FW); FW5.0 - with 5.0 L of FW Contr - contrast with and without whey; Ferm - contrast of W and FW; Level - contrast of whey levels; Interaction - contrast of W and FW in the different levels. $\mathrm{CV}$ - coefficient of variation.

Effect of supplementation with whey on the apparent nitrogen balance was observed $(\mathrm{P}<0.10)$. Supplementation with whey improved the apparent nitrogen balance. On average, the apparent nitrogen balance of animals which did not receive whey and animals that were supplemented with whey were $-53.50 \mathrm{~g} /$ day and $0.96 \mathrm{~g} /$ day, respectively.

The nitrogen assimilation by microorganisms is only possible when there is enough power; otherwise, the excess of nitrogen is lost (Marini \& Amburgh, 2003). The best apparent nitrogen balance of animals on a whey diet is possibly due to the increased availability of energy for nitrogen assimilation of food by rumen microorganisms, reducing losses of nitrogen in the form of urine.

Significant effect $(\mathrm{P}<0.10)$ of the whey fermentation was found on Nmic and MEF. The animals that received the non-fermented whey had $157.51 \mathrm{~g} /$ day of Nmic and $207.57 \mathrm{~g}$ of microbial $\mathrm{CP} / \mathrm{kg}$ of $\mathrm{TDN}$, while animals that were supplemented with fermented whey showed $86.68 \mathrm{~g} /$ day of Nmic and 117.03 of microbial CP/kg of TDN. Supplementation with fermented whey decreased the intestinal flow of microbial nitrogen and microbial efficiency in relation to non-fermented whey.

The bacterial strains Enterococcus faecium and Veilonella parvula produce propionic acid from the lactose from whey (Melo, 2007). Oliveira et al. (2011) found that propionic acid is not used by rumen microorganisms in the fermentation process, as an energy source. The nonfermented whey, due to the fact that it presents high lactose content, is a source of energy for the rumen microorganisms so that they can assimilate highly degradable nitrogen of the diets. The fermented whey, having already undergone a process of fermentation, had its lactose, which could serve as an energy source for rumen microorganisms, transformed into organic acids.

Thus, the non-fermented whey provided greater efficiency of microbial synthesis in relation to the fermented whey, possibly by providing a better relationship between nitrogen compounds and readily available energy for rumen microorganisms, which did not happen when there was fermented whey in the diet, in which much of the power source had been transformed into propionic acid and, therefore, could not be used by rumen microorganisms. The greater efficiency of microbial synthesis results in higher production of microbial mass, which, as a consequence, results in higher intestinal flow of microbial nitrogen.

The animals which were fed unfermented whey, had, then, higher intestinal flow of microbial nitrogen than the ones fed fermented whey, due to the greater availability of energy for rumen microbial growth.

In in vitro experiments, stimulation in the growth of rumen bacteria was observed when it was in the middle of fermented whey (Table 2). As a result of further stimulation on microbial growth, a higher efficiency of microbial synthesis is expected. However, when comparing the results of microbial efficiency of animals fed with fermented whey with animals receiving unfermented whey, lower efficiency was verified when the fermented whey was included in the diet of cattle.

Although it was observed, in vitro, that the fermented whey stimulated microbial growth, it was found that, when 
added in the fermented whey containing active cultures the culture medium, it did not stimulate the microbial growth in vitro due to the fact that it competed with the rumen microorganisms for the substrate. The fermented whey used in vivo contained micro-organisms in its active form. Thus, the lower efficiency of microbial synthesis and lower intestinal flow of microbial nitrogen of the animals receiving fermented whey compared with unfermented whey may be due to a combination of microorganisms and lower concentration of active energy source (lactose) in the fermented whey, which explains the contradictory results regarding the in vitro study. These two factors may have excelled on the stimulant effect of the components of fermented whey, such as organic acids, on the protein production.

The characteristics of Enterococcus faecium and Veilonella parvula of survival and competition with the observed in vitro rumen bacteria proved to be negative, whereas the presence of active Enterococcus faecium and Veilonella parvula in fermented whey, when added in the diet of heifers, negatively influenced the efficiency of using nitrogen in the rumen.

\section{Conclusions}

Fermented whey containing active cultures of Enterococcus faecium and Veilonella parvula bacteria does not stimulate the growth of rumen bacteria. Supplementation with bovine whey, fermented by an Enterococcus faecium and Veilonella parvula consortium, implies positive effects on food intake and negative effects on nitrogen utilization by rumen microorganisms when compared with the unfermented whey. Thus, the fermentation process of whey in the evaluated conditions does not improve the physiological responses of heifers supplemented with 2.5 or $5.0 \mathrm{~L}$ of whey.

\section{References}

BRADFORD, M.M. A rapid and sensitive method for the quantitation of microgram quantities of protein utilizing the principle of protein-dye binding. Analytical Biochemistry, v.72, p.248-254, 1976

CASALI, A.O.; DETMANN, E.; VALADARES FILHO, S.C. et al. Influência do tempo de incubação e tamanho de partículas sobre os teores de compostos indigestíveis em alimentos e fezes bovinas obtidos por procedimento in situ. Revista Brasileira de Zootecnia, v.37, n.2, p.335-342, 2008

CECAVA, J.M.; MERCHEN, N.R.; GAY, L.C. et al. Composition of ruminal bacteria harvested from steers as influenced by dietary energy level, feeding frequency, and isolation techniques. Journal of Dairy Science, v.73, p.2480-2488, 1990.

CHANEY, A.L.; MARBACH, E.P. Modified reagents for determination of urea and ammonia. Clinical Chemistry, v.8, p.130-132, 1962.

CHEN, X.B.; GOMES, M.J. Estimation of microbial protein supply to sheep and cattle based on urinary excretion of purine derivatives - an overview of the technical details. Buchsburnd Aberdeen: Rowett Research Institute, 1992. 21p.

CHIZZOTTI, M.L. Avaliação da casca de algodão para novilhos de origem leiteira e determinação da excreção de creatinina e produção de proteína microbiana em novilhas e vacas leiteiras. 2004. 141f. Dissertação (Mestrado em Zootecnia) - Universidade Federal de Viçosa, Viçosa, MG.

KHAMPA, S.; WANAPAT, M. Manipulation of rumen fermentation with organic acids supplementation in ruminants raised in the tropics. Pakistan Journal of Nutrition, v.6, supl.1, p.20-27, 2007.

KUNG, L.; HUBER, J.T.; KRUMMREY, J.D. et al. Influence of adding malic acid to dairy cattle rations on milk production, rumen volatile acids. Journal of Dairy Science, v.65, p.1170-1174, 1982.

KREHBIEL, C.R.; RUST, S.R.; ZHANG, G. et al. Bacterial directfed microabials in ruminant diets: performance response and mode of action. Journal of Dairy Science, v.81, n.1, p.E120E132, 2003.

LICITRA, G.; HERNANDEZ, T.M.; Van SOEST, P.J. Standardization of procedures for nitrogen fractionation of ruminant feeds. Animal Feed Science and Technology, n.57, p.347-358, 1996.

MAGALHÃES, K.A.; VALADARES FILHO, S.C.; DETMANN, E. et al. Evaluation of indirect methods to estimate the nutritional value of tropical feeds for ruminants. Animal Feed Science and Technology, v.155, n.1, p. 44-54, 2010.

MERCHEN, N.R. Digestion, absorcion y excrecion en los ruminiantes. In: CHURCH, D.C. (Ed). El ruminante fisiología digestive y nutrición. 4.ed. Zaragoza: Acríbia, 1993. 641p.

MARINI, J.C.; VAN AMBURGH, M.E. Nitrogen metabolism and recycling in Holstein heifers. Journal of Animal Science, v.81, n.2, p.545-552, 2003.

MELO, M.R. Produção de ácido propiônico em soro de leite por bactéria do rúmen bovino. 2007. 54f. Dissertação (Mestrado em Zootecnia) - Universidade Federal de Viçosa, Viçosa, MG.

MERTENS, D.R. Gravimetric determination of amylase-treated neutral detergent fiber in feeds with refluxing in beakers or crucibles: collaborative study. Journal of AOAC International, v.85, p.1217-1240, 2002.

NATIONAL RESEARCH COUNCIL - NRC. Nutriente requeriments of beef catlle. Washington: National Acadeny of Science, 1996. $232 p$.

OLIVEIRA, J.S.; QUEIROZ, A.C.; MANTOVANI, H.C. et al. Effect of propionic and lactic acids on in vitro ruminal bacteria growth. Revista Brasileira de Zootecnia, v.40, n.5, p.1121-1127, 2011.

RIBEIRO, M.D.; PEREIRA, J.C.; QUEIROZ, A.C. et al. Influence of intraruminal infusion of propionic acid and forage to concentrate levels on intake, digestibility and rumen characteristics in young bulls. Revista Brasileira de Zootecnia, v.38, n.5, p.948-955, 2009.

SILVA, D.J.; QUEIROZ, A.C. Análise de alimentos: métodos químicos e biológicos. 3.ed. Viçosa, MG: UFV, 2002. 235p.

STRADIOTTI JUNIOR, D.; QUEIROZ, A.C.; LANA; R.P. et al. Ação de extrato de própolis sobre a fermentação in vitro de diferentes alimentos. In: REUNIÃO ANUAL DA SOCIEDADE BRASIlEIRA DE ZOOTECNIA, 38., 2001, Recife. Anais... Piracicaba: Sociedade Brasileira de Zootecnia, 2001. (CD-ROM). 
USHIDA, K.; LASSALAS, B.; JOUANY, J.P. Determination of assay parameters for RNA analysis in bacterial and duodenal samples by spectrophotometry. Influence of treatment and preservation. Reproduction Nutrition Development, v.25, p.1037-1046, 1985.
VERBIC, J.; CHEN, X.B.; MACLEOD, N.A. et al. Excretion of purine derivatives by ruminants. Effect of microbial nucleic acid infusion on purine derivative excretion by steers. Journal of Agricultural Science, v.114, p.243-248, 1990. 